\title{
Evaluation of phytotoxicity of municipal landfill leachate before and after biological treatment
}

\author{
Klauck, CR. ${ }^{a}$, Rodrigues, MAS. ${ }^{a, b}$ and Silva, LB. ${ }^{a, b *}$ \\ aPrograma de Pós-graduação em Qualidade Ambiental, Universidade Feevale, Novo Hamburgo, RS, Brazil \\ ${ }^{\mathrm{b}}$ Grupo de Pesquisa em Indicadores de Qualidade Ambiental, Universidade Feevale, \\ Rodovia RS-239 Km 2755, CEP 93352-000, Novo Hamburgo, RS, Brazil \\ *e-mail: lucianosilva@feevale.br
}

Received: May 24, 2013 - Accepted: August 28, 2013 - Distributed: May 31, 2015

\begin{abstract}
In the present study, leachate toxicity of a municipal solid waste landfill located in the Sinos River Valley region (southern Brazil) was evaluated using plant bioassays. Leachate toxicity was assessed by analysis of seed germination and root elongation of lettuce (Lactuca sativa L.) and rocket plant (Eruca sativa Mill.) and root elongation of onions (Allium cepa $\mathrm{L}$.). Bioassays were performed by exposing the seeds of $L$. sativa and E. sativa and the roots of $A$. cepa to raw leachate, treated leachate (biological treatment) and negative control (tap water). The levels of metals detected in both samples of leachate were low, and raw leachate showed high values for ammoniacal nitrogen and total Kjeldahl nitrogen. There is a reduction in the values of several physicochemical parameters, which demonstrates the efficiency of the treatment. Both L. sativa and A. cepa showed a phytotoxic response to landfill leachate, showing reduced root elongation. However, the responses of these two plant species were different. Root elongation was significantly lower in A. cepa exposed to treated leachate, when compared to negative control, but did not show any difference when compared to raw leachate. In $L$. sativa, seeds exposed to the raw leachate showed significant reduction in root elongation, when compared to treated leachate and negative control. Seed germination showed no difference across the treatments. The results of the study show that plant species respond differently and that municipal solid waste landfill leachate show phytotoxicity, even after biological treatment.
\end{abstract}

Keywords: plant bioassays, water pollution, wastewater treatment, toxic effects.

\section{Avaliação da fitotoxicidade de chorume de aterro sanitário antes e após tratamento biológico}

\section{Resumo}

No presente trabalho, a toxicidade do lixiviado (chorume) de um aterro sanitário municipal, localizado na região do Vale do Rio dos Sinos, foi avaliada utilizando bioensaios em plantas. A toxicidade do chorume foi analisada pelo teste de germinação e crescimento radicular de alface (Lactuca sativa L.) e rúcula (Eruca sativa Mill.) e pelo teste de crescimento radicular em cebola (Allium cepa L.). Os bioensaios foram realizados com a exposição de sementes de $L$. sativa e E. sativa e raízes de A. cepa a amostras de chorume bruto, tratado por processo biológico e controle negativo (água de abastecimento público). Os níveis de metais detectados nas amostras de chorume foram baixos, e o chorume bruto apresentou valores elevados de nitrogênio amoniacal e nitrogênio Kjeldahl total. Ocorreu redução nos valores de vários parâmetros físico-químicos, demonstrando a eficiência do tratamento biológico. Os resultados indicam fitotoxicidade do chorume em L. sativa e A. cepa, evidenciada pela redução do crescimento radicular. Entretanto, as respostas destas duas espécies diferiram. O crescimento radicular foi significativamente inferior em A. cepa exposta ao chorume tratado quando comparado ao controle negativo, mas não apresentou diferença quando comparado ao chorume bruto. Em L. sativa, a exposição das sementes ao chorume bruto causou redução no crescimento radicular quando comparado com o chorume tratado e controle negativo. Não foram observadas diferenças entre os tratamentos para o parâmetro germinação de sementes. Os resultados deste trabalho indicam que as espécies de plantas estudadas são diferentes em suas respostas e que o chorume apresenta toxicidade, mesmo após o tratamento biológico.

Palavras-chave: bioensaios com plantas, poluição da água, tratamento de efluentes, efeitos tóxicos. 


\section{Introduction}

One of the main environmental problems caused by the urbanisation in cities concerns the disposal of municipal solid waste (Renou et al., 2008). Waste disposal in landfills is an increasingly common practice in large cities (Abrelpe, 2011), and generates large volumes of leachate as the product of waste decomposition and percolation of rainwater. Leachate is a dark liquid, with unpleasant odour; it is highly toxic and should be handled properly before its release in receiving bodies (Baun et al., 2003; Foul et al., 2009).

The most common conventional treatments for this type of effluent are biological aerobic and anaerobic treatments (Renou et al., 2008). However, this kind of treatment often presents low efficiency in the case of leachate coming from old landfills, due to reduced biodegradable fraction, presence of high molecular weight substances (Mahmud et al., 2012), in addition to high concentrations of ammoniacal nitrogen and other highly toxic compounds, which inhibit the biological treatment process and reduce the leachate treatability by conventional processes (Oller et al., 2011; Rocha et al., 2011).

Hazard assessment of landfill leachate is traditionally based on the evaluations of individual chemicals identified through chemical analysis. However, chemical data alone do not allow for the evaluation of toxic effects. Toxicity bioassays, in contrast to physicochemical analysis, integrate the biological effects of all compounds present and other factors, such as bioavailability and toxicants interactions (Žaltauskaitė and Čypaitė, 2008). Some studies show that leachate can cause deleterious effects on organisms at various trophic levels (Bakare and Osibanjo, 2000; Christensen et al., 2001; Bortolotto et al., 2009; $\mathrm{Li}$ et al., 2010). Among the various toxicity tests available, the seed germination and root elongation is a widely used, quick and accurate phytotoxicity test, showing sensitivity, simplicity, low cost and suitability for unstable chemicals or samples (Wang et al., 2001). Different model species are used in bioassays, including lettuce (Lactuca sativa L.), rocket plant (Eruca sativa Mill.) and onions (Allium cepa L.) (Barbero et al., 2001).

In the Sinos River Basin, located in the state of Rio Grande do Sul, Brazil, a large portion of municipal landfills has been disabled. However, in these locations, there is still generation and treatment of leachate, which is ultimately released in the water resources. The water quality in the basin is influenced by the direct discharge of domestic and industrial sewage, which have the potential to cause toxic effects on genetic and cellular levels (Blume et al., 2010; Scalon et al., 2010; Rechenmacher et al., 2010; Costa and Droste, 2012). Although the release of leachate poses an environmental risk, the effectiveness of its treatment and its toxicity in the Sinos River Basin were not assessed. This study aims to evaluate the phytotoxicity of leachate from a municipal landfill in three plant species, before and after biological treatment.

\section{Material and Methods}

\subsection{Sample collection}

The leachate collection took place during September 2012 (spring season), in a municipal solid waste landfill located in a large municipality in the Sinos River Valley region. The landfill is approximately 50 years old and has been disabled, but its pits still generate leachate, which passes through a biological treatment system (biodegradation is carried out by microorganisms in a treatment pond).

An aliquot of raw leachate was collected at the input and another aliquot of treated leachate was collected at the output of the biological treatment pond.

\subsection{Physicochemical analyses of the samples}

Immediately after collection, the samples were sent for physicochemical characterisation and the following parameters were determined: chlorides, conductivity, chemical oxygen demand (COD), biochemical oxygen demand $\left(\mathrm{BOD}_{5}\right)$ total phosphorus, ammoniacal nitrogen, nitrate, nitrite, total Kjeldahl nitrogen, $\mathrm{pH}$, turbidity, metals (cadmium, lead, chromium, zinc, nickel, manganese and iron). All analyses were carried out at the laboratories of Feevale University, according to the methods described in Standard Methods for Examination of Water and Wastewater (APHA, 2005).

\subsection{Allium cepa bioassay}

Onion bulbs (Allium cepa) were purchased commercially and kept in a moisture-free location, protected from light. Prior to the test, roots that were old and dried were removed. In order to stimulate root growth, onions were kept in tap water for a period of 24 hours before exposure. Leachate samples were tested at a concentration of $100 \%$. A negative control group was treated with tap water. Five onion bulbs were exposed to each treatment at room temperature and insulated from direct sunlight for a period of 48 hours. At the end of the exposure period, the length of the three longest roots in each bulb was measured. The average length of the roots in each treatment was calculated and compared to the growth in the control group. Toxicity was assessed by inhibition of root growth in the leachate samples, when compared to the control group.

\subsection{Bioassay with Lactuca sativa and Eruca sativa seeds}

The germination and root growth tests were performed using Lactuca sativa and Eruca sativa seeds obtained from local retailers. Protocol consisted of exposure of the Lactuca sativa and Eruca sativa seeds in Petri dishes prepared with a filter paper and $5 \mathrm{~mL}$ of the raw and treated leachate samples, and tap water for the control group. For each treatment, fifty seeds were exposed in one Petri dish. Time of exposure was 120 hours, at room temperature and insulated from direct light. At the end of the treatment, germination rate and root growth were estimated. 


\subsection{Statistical analysis}

The statistical analysis was performed using ANOVA, followed by the Tukey multiple comparison test, when appropriate. Seed germination was analysed by the Chi-square test. All analyses were carried out using the Statistical Package for the Social Sciences (SPSS) 15.0 for Windows, considering a significance level of $p \leq 0.05$.

\section{Results}

The results of the physicochemical analyses are presented in Table 1. Among the parameters evaluated in the sample of raw leachate, the nitrogen compounds in the series, ammoniacal nitrogen and total Kjeldahl nitrogen, showed very high values. The other parameters, with the exception of manganese, were found to be within the emission limits established in the Consema Resolution No. 128/2006 (which sets emission standards for the discharge of liquid effluent to superficial waters in the State of the Rio Grande do Sul). A change was observed in the characteristics of the leachate after the biological treatment. There is a reduction in the values of conductivity, $\mathrm{BOD}_{5}$, COD, chlorides, total phosphorus, turbidity and metals, which demonstrates the efficiency of the treatment. In contrast, an increase in the concentration of nitrite and nitrate was observed. Total Kjeldahl Nitrogen parameter was still found to be outside the limit set by state law (20.0 mg/L). The biodegradability of the leachate obtained by the ratio $\mathrm{BOD}_{5} / \mathrm{COD}$ ratio shows low values, both for the raw sample $(0.17)$ and for the treated sample $(0.23)$.

The results of the toxicity assessment in A. cepa are presented in Table 2. Both leachate samples showed a reduction in root growth, but only post-biological treatment leachate showed a significantly lower growth rate (64\%) than the control $(\mathrm{p}=0.036)$.

The results of seed germination and root growth in Lactuca sativa and Eruca sativa are shown in Table 3. The exposure of L. sativa and E. sativa seeds to the raw and treated leachate samples did not cause a significant reduction in the germination rate, when compared to the control group. For the other toxicity parameter assessed, namely root growth, the raw leachate caused a significant

Table 1. Results of physicochemical analyses of the samples of raw and treated leachate and effluent emission standards of state law in effect (Consema Resolution No. 128/06, Rio Grande do Sul, 2006), considering a flow rate of up to $100 \mathrm{~m}^{3}$ per day.

\begin{tabular}{lrcc}
\hline & Raw & Treated & Consema Resolution \\
\hline Chlorides $(\mathrm{mg} / \mathrm{L})$ & 323.50 & 184.30 & - \\
Conductivity $(\mathrm{mS} / \mathrm{cm})$ & 3.83 & $>1.41$ & - \\
$\mathrm{BOD}_{5}\left(\mathrm{mg} \mathrm{O}_{2} / \mathrm{L}\right)$ & 60.00 & 35.00 & 150.00 \\
$\mathrm{COD}\left(\mathrm{mg} \mathrm{O}_{2} / \mathrm{L}\right)$ & 346.30 & 153.80 & 360.00 \\
Total phosphorus $(\mathrm{mg} / \mathrm{L})$ & 1.62 & 0.14 & 4.00 \\
Nitrate $(\mathrm{mg} / \mathrm{L})$ & 1.64 & 30.17 & - \\
Nitrite $(\mathrm{mg} / \mathrm{L})$ & 0.05 & 0.75 & - \\
Ammoniacal nitrogen $(\mathrm{mg} / \mathrm{L})$ & 221.57 & 15.68 & 20.00 \\
Total Kjeldahl Nitrogen $(\mathrm{mg} / \mathrm{L})$ & 348.51 & $113.68^{*}$ & 20.00 \\
pH & 7.78 & 7.25 & -9.0 \\
Turbidity $(\mathrm{NTU})$ & 52.60 & 2.20 & - \\
Cadmium $(\mathrm{mg} / \mathrm{L})$ & 0.00 & 0.00 & 0.10 \\
Lead $(\mathrm{mg} / \mathrm{L})$ & 0.05 & 0.05 & 0.20 \\
Chromium $(\mathrm{mg} / \mathrm{L})$ & 0.00 & 0.00 & 1.00 \\
Manganese $(\mathrm{mg} / \mathrm{L})$ & 1.18 & 0.47 & 1.00 \\
Nickel $(\mathrm{mg} / \mathrm{L})$ & 0.04 & 0.04 & 2.00 \\
Zinc $(\mathrm{mg} / \mathrm{L})$ & 0.06 & 0.03 & 10.00 \\
Iron $(\mathrm{mg} / \mathrm{L})$ & 1.02 & 0.26 & \\
Biodegradability $\left(\mathrm{BOD}_{5} / \mathrm{COD}\right)$ & 0.17 & 0.23 & \\
\hline
\end{tabular}

*Value above the state limit established for effluent release.

Table 2. Root growth of A.cepa exposed to samples of raw and treated leachates, and comparison with negative control.

\begin{tabular}{ccc}
\hline Treatment & Root growth $(\mathbf{c m})$ & Relative growth $(\mathbf{\%}) *$ \\
\hline Control & $4.22 \pm 1.11^{\mathrm{a}}$ & 100 \\
Raw & $3.26 \pm 0.47^{\mathrm{ab}}$ & 77.3 \\
Biological & $2.74 \pm 0.69^{\mathrm{b}}$ & 64.9 \\
& $\mathrm{p}=0.036$ & \\
\hline
\end{tabular}

*Root growth when compared to control group. ${ }^{\text {ab}}$ Values marked with the same letter do not present significant variation. 
Table 3. Seed germination and root growth in L. sativa and E. sativa exposed to samples of raw and treated leachate and comparison with negative control.

\begin{tabular}{ccc}
\hline Species/Treatment & Germination (\%) & Root growth (cm) \\
\hline Lactuca sativa & & \\
Control & 100 & $1.55 \pm 0.42^{\mathrm{a}}$ \\
Raw & 90 & $0.43 \pm 0.26^{\mathrm{b}}$ \\
Biological & 90 & $1.54 \pm 0.79^{\mathrm{a}}$ \\
& $\mathrm{p}=0.43$ & $\mathrm{p}=0.0001$ \\
Eruca sativa & & \\
Control & 80 & $1.73 \pm 0.70$ \\
Raw & 80 & $0.85 \pm 0.62$ \\
Biological & 90 & $1.47 \pm 0.76$ \\
& $\mathrm{p}=0.77$ & $\mathrm{p}=0.055$ \\
\hline
\end{tabular}

${ }^{\mathrm{ab}}$ Values marked with the same letter do not present significant variation.

reduction $(\mathrm{p}=0.0001)$ in L. sativa, when compared to both the negative control and the treated leachate. The same effect was observed in E. sativa, but in this case the differences were closer to the statistical significance threshold $(\mathrm{p}=0.055)$.

\section{Discussion}

The monitoring of landfill leachate after treatment, in order to ensure safe levels for its disposal in the environment, can be accomplished through a series of physicochemical parameters (Barker and Stuckey, 1999; Baun and Christensen, 2004). However, none of these parameters alone is able to determine whether the sample may have toxic effects on aquatic biota (Rizzo, 2011). In this sense, the bioassays are useful tools for assessing the risks to the biota posed by pollutants (Knie and Lopes, 2004). In southern Brazil, studies assessing the toxicity of landfill leachates are still scarce (Bortolotto et al., 2009).

Germination and root growth tests allow for an assessment of acute toxicity, both of a pure pollutant and of a complex mixture (Torres et al., 2003). Toxicity tests based on seed germination and root growth have been proposed by government agencies as part of the evaluation of the potential for contamination of waste and effluents disposed into the environment (USEPA, 1996). Among the possible environmental contaminants, ammonium, volatile organic acid, heavy metal and salt contents can cause harmful effects on plant development, by inhibiting seed germination or root growth (Varnero et al., 2007).

In this study, the seed germination parameter was considered to be less sensitive to the toxicity of the leachate. Similar results have also been obtained by other authors (Kapustka et al., 1995; Gunderson et al., 1997; Meier et al., 1997; Marčiulionienė and Montvydienè, 2002). In this aspect, substances considered to be toxic seem to not directly affect the process of ontogeny of the seed, in the transition from heterotrophic to autotrophic metabolism. The direct contact of the meristematic tissue of the root with the toxic effluent probably causes an increased sensitivity, influencing permeability, production of growth hormones and cell differentiation (Kummerová and Kmentová, 2004).
The evaluation of root growth indicates that Lactuca sativa and Allium cepa are sensitive to the toxic effects of substances present both in raw and treated leachates. According to Žaltauskaitè and Čypaitė (2008), root growth is the parameter with the highest sensitivity in the evaluation of toxicity using plant species. Raw leachate was found to be toxic only for L.sativa. Studies have found that the lettuce seed is very sensitive to the presence of metals and organic compounds, which makes it suitable for testing the toxicity of effluents (Wang, 1987; Toussaint et al., 1995). The inhibition of L. sativa root growth in raw leachate samples has also been reported by Žaltauskaite and Čypaite (2008), with root growth inhibition reaching up to $80 \%$, when compared to the control. In contrast, after biological treatment, the leachate was found to be toxic only for A. сера. The reason for this variable response on the tested species could be attributed to inherent differences between the species, such as tissue permeability, differential uptake and metabolism (Cutillo et al. 2003).

The physicochemical analyses indicate that the leachate presents most parameters within the boundaries of what is acceptable by law, except for nitrogen compounds. However, it is worth noting that some parameters detected in high concentrations in this study, such as chloride, nitrate, nitrite and conductivity, have no legal limits for disposal. The levels of metals detected in both samples of leachate were low, thus indicating a typical domestic waste landfill (Christensen et al., 2001).

Some results of this study cast doubt on the apparent effectiveness of biological treatment, which is evidenced only when considering the parameters contained in the legislation. The biodegradability of the treated leachate, obtained by the $\mathrm{BOD}_{5} / \mathrm{COD}$ ratio, was 0.23 , while the minimum value for an effective biological treatment is 0.3 (Scott and Ollis, 1995; Marco et al., 1997; Parra et al., 2002). Furthermore, the phytotoxicity tests showed that toxicity also occurs after conventional biological treatment, thus corroborating the results found by other studies on the toxicity of treated effluents (Oral et al., 2007; De Nicola et al., 2007; Bortolotto et al., 2009). This occurs because some toxic chemicals will not undergo degradation 
during wastewater treatment, owing to a high degree of persistence. Moreover, waste treatment does not always reduce the toxicity of an effluent and, in some instances, may increase toxicity (Claxton et al., 1998).

This study has shown that the higher plants species L. sativa and $A$. cepa can be effectively used to assess toxicity of landfill leachate and that an integrated analysis of wastewaters should be considered, in which chemical analysis can determine the presence and concentrations of compounds, while bioassays can evaluate the toxic and synergistic effects of these compounds. Regarding the toxicity of leachate, additional knowledge is required in order to address the potential toxicity of untreated leachate and the efficiency of treatment technology considering the influence of environmental conditions on the dynamics of the decomposition processes that take place in the landfill.

\section{References}

American Public Health Association - APHA, 2005. Standard methods for the examination of water and wastewater. 21 st ed. Washington: APHA. 1220 p.

Associação Brasileira de Empresas de Limpeza Pública e Resíduos Especiais -ABRELPE, 2011. Panorama dos resíduos sólidos no Brasil. vol. 1. São Paulo: ABRELPE. 186 p.

BAKARE, AA. and OSIBANJO, O., 2000. Effect of simulated leachate on chromossomes and mitosis on roots of Allium cepa (L.). Journal of Environmental Biology, vol. 21, no. 3, p. 263-271.

BARBERO, P., BELTRAMI, M., BAUDO, R. and ROSSI, D., 2001. Assessment of Lake Orta sediments phytotoxicity after the liming treatment. Journal of Limnology, vol. 60, no. 2, p. 269-276. http://dx.doi.org/10.4081/jlimnol.2001.1.269.

BARKER, DJ. and STUCKEY, DC., 1999. A review of soluble microbial products (SMP) in wastewater treatment systems. Journal of Water Research, vol. 33, no. 14, p. 3063-3082. http:// dx.doi.org/10.1016/S0043-1354(99)00022-6.

BAUN, A., REITZEL, LA., LEDIN, A., CHRISTENSEN, TH. and BJERG, PL., 2003. Natural attenuation of xenobiotic organic compounds in a landfill leachate plume (Vejen, Denmark). Journal of Contaminant Hydrology, vol. 65, no. 3-4, p. 269-291. http:// dx.doi.org/10.1016/S0169-7722(03)00004-4. PMid:12935953.

BAUN, DL. and CHRISTENSEN, TH., 2004. Speciation of heavy metals in landfill leachate: a review. Waste Management \& Research: the Journal of the International Solid Wastes and Public Cleansing Association, ISWA, vol. 22, no. 1, p. 3-23. http://dx.doi.org/10.1177/0734242X04042146. PMid:15113110.

BLUME, KK., MACEDO, JC., MENEGUZZI, A., SILVA, LB., QUEVEDO, DM. and RODRIGUES, MAS., 2010. Water quality assessment of the Sinos River, Southern Brazil. Brazilian Journal of Biology $=$ Revista Brasileira de Biologia, vol. 70, no. 4, supplement, p. 1185-1193. http://dx.doi.org/10.1590/S151969842010000600008. PMid:21225160.

BORTOLOTTO, T., BERTOLDO, JB., SILVEIRA, FZ., DEFAVERI, TM., SILVANO, J. and PICH, CT., 2009. Evaluation of the toxic and genotoxic potential of landfill leachates using bioassays. Environmental Toxicology and Pharmacology, vol. 28, no. 2, p. 288-293. http://dx.doi.org/10.1016/j.etap.2009.05.007. PMid:21784018.
CHRISTENSEN, TH., KJELDSEN, P., BJERG, PL., JENSEN, DL., CHRISTENSEN, JB., BAUN, A., ALBRECHTSEN, HJ. and HERON, G., 2001. Biogeochemistry of landfill leachate plumes. Applied Geochemistry, vol. 16, no. 7-8, p. 659-718. http://dx.doi. org/10.1016/S0883-2927(00)00082-2.

CLAXTON, LD., HOUK, VS. and HUGHES, TJ., 1998. Genotoxicity of industrial wastes and effluents. Mutation Research, vol. 410, no. 3, p. 237-243. http://dx.doi.org/10.1016/S1383-5742(98)000088. PMid:9630652.

COSTA, GM. and DROSTE, A., 2012. Genotoxicity on Tradescantia pallida var. purpurea plants exposed to urban and rural environments in the metropolitan area of Porto Alegre, southern Brazil. Brazilian Journal of Biology $=$ Revista Brasileira de Biologia, vol. 72, no. 4, p. 801-806. http://dx.doi.org/10.1590/ S1519-69842012000500004. PMid:23295507.

CUTILlo, F., D’ABRosCA, B., DELlaGRECA, M., DI MARINO, C., GOLINO, A., PREVITERA, L. and ZARRELLI, A., 2003. Cinnamic acid amides from Chenopodium album: effects on seeds germination and plant growth. Phytochemistry, vol. 64, no. 8, p. 1381-1387. http://dx.doi.org/10.1016/S00319422(03)00511-9. PMid:14630003.

DE NICOLA, E., MERIÇ, S., DELLA ROCCA, C., GALLO, M., IACCARINO, M., MANINI, P., PETRUZZELLI, D., BELGIORNO, V., CHEGGOUR, M., DI GENNARO, A., MOUKRIM, A., TÜNAY, O. and PAGANO, G., 2007. Wastewater toxicity of tannin- versus chromium-based leather tanneries in Marrakesh, Morocco. Archives of Environmental Contamination and Toxicology, vol. 53, no. 3, p. 321-328. http://dx.doi.org/10.1007/s00244-0060181-5. PMid:17728989.

FOUL, A., AZIZ, HA., ISA, MH. and HUNG, Y-T., 2009. Primary treatment of anaerobic landfill leachate using activated carbon and limestone: batch and column studies. Waste Management (New York, N.Y.), vol. 44, no. 4, p. 282-298.

GUNDERSON, CA., KOSTUK, JM., GIBBS, MH., NAPOLITANO, GE., WICKER, LF., RICHMOND, JE. and STEWART, AJ., 1997. Multispecies toxicity assessment of compost produced in bioremediation of an explosives-contaminated sediment. Environmental Toxicology and Chemistry, vol. 16, no. 12, p. 2529-2537. http://dx.doi.org/10.1002/etc.5620161214.

KAPUSTKA, LA., LIPTON, J., GALBRAITH, H., CACELA, D. and LEJEUNE, K., 1995. Metal and arsenic impacts to soils, vegetation communities and wildlife habitat in Southwest Montana uplands contaminated by smelter emissions: II. Laboratory phytotoxicity studies. Environmental Toxicology and Chemistry, vol. 14, no. 11, p. 1905-1912. http://dx.doi.org/10.1002/etc.5620141112.

KNIE, JLW. and LOPES, EWB. 2004. Testes ecotoxicológicos: métodos, técnicas e aplicações. Florianópolis: FATMA. 289 p.

KUMMEROVÁ, M. and KMENTOVÁ, E., 2004. Photoinduced toxicity of fluoranthene on germination and early development of plant seedling. Chemosphere, vol. 56, no. 4, p. 387-393. http:// dx.doi.org/10.1016/j.chemosphere.2004.01.007. PMid:15184002.

LI, H., HAN, M., HOU, L., LI, G. and SANG, N., 2010. Landfill leachate ingestion induces protein oxidation and DNA-protein crosslinks in mouse viscera. Journal of Hazardous Materials, vol. 174, no. 1-3, p. 54-58. http://dx.doi.org/10.1016/j.jhazmat.2009.09.015. PMid:19783094.

MAHMUD, K., HOSSAIN, MD. and SHAMS, S., 2012. Different treatment strategies for highly polluted landfill leachate in developing countries. Waste Management (New York, N.Y.), vol. 32, no. 11, 
p. 2096-2105. http://dx.doi.org/10.1016/j.wasman.2011.10.026. PMid:22088960.

MARČIULIONIENĖ, D. and MONTVYDIENĖ, D., 2002. Application of plants test-organisms in ecotoxicological investigations. Botanica Lithuanica, vol. 4, p. 75-90.

MARCO, A., ESPLUGAS, S. and SAUM, G., 1997. How and why to combine chemical and biological processes for wastewater treatment. Water Science and Technology, vol. 35, no. 4, p. 321327. http://dx.doi.org/10.1016/S0273-1223(97)00041-3.

MEIER, JR., CHANG, LW., JACOBS, S., TORSELLA, J., MECKES, MC. and SMITH, MK., 1997. Use of plant and earthworm bioassays to evaluate remediation of soil from a site contaminated with polychlorinated biphenyls. Environmental Toxicology and Chemistry, vol. 16, no. 5, p. 928-938. http:// dx.doi.org/10.1002/etc.5620160512.

OLLER, I., MALATO, S. and SÁNCHEZ-PÉREZ, JA., 2011. Combination of Advanced Oxidation Processes and biological treatments for wastewater decontamination--a review. The Science of the Total Environment, vol. 409, no. 20, p. 4141-4166. http:// dx.doi.org/10.1016/j.scitotenv.2010.08.061. PMid:20956012.

ORAL, R., MERIÇ, S., DE NICOLA, E., PETRUZZELLI, D., DELLA ROCCA, C. and PAGANO, G., 2007. Multi-species toxicity evaluation of a chromium-based leather tannery wastewater. Desalination, vol. 211, p. 48-57. http://dx.doi.org/10.1016/j. desal.2006.02.084.

PARRA, S., MALATO, S. and PULGARIN, C., 2002. New integrated photocatalytic-biological flow system using supported $\mathrm{TiO} 2$ and fixed bacteria for the mineralization isoproturon. Applied Catalysis B: Environmental, vol. 36, no. 2, p. 131-144. http:// dx.doi.org/10.1016/S0926-3373(01)00293-4.

RECHENMACHER, C., SIEBEL, AM., GOLDONI, A., KLAUCK, CR., SARTORI, T., RODRIGUES, MT., RODRIGUES, MAS., GEHLEN, G., ARDENGHI, PG. and SILVA, LB., 2010. A multibiomarker approach in rats to assess the impact of pollution on Sinos River, Southern Brazil. Brazilian Journal of Biology = Revista Brasileira de Biologia, vol. 70, no. 4, supplement, p. 1223-1230. http://dx.doi.org/10.1590/S1519-69842010000600012. PMid:21225164.

RENOU, S., GIVAUDAN, JG., POULAIN, S., DIRASSOUYAN, F. and MOULIN, P., 2008. Landfill leachate treatment: review and opportunity. Journal of Hazardous Materials, vol. 150, no. 3, p. 468-493. http://dx.doi.org/10.1016/j.jhazmat.2007.09.077. PMid:17997033.

Rio Grande do Sul. Conselho Estadual do Meio Ambiente CONSEMA, 2006. Resolução $n^{\circ} 128 / 06$. Dispõe sobre a fixação de Padrões de Emissão de Efluentes Líquidos para fontes de emissão que lancem seus efluentes em águas superficiais no Estado do Rio Grande do Sul. Diário Oficial do Estado, Porto Alegre. $7 \mathrm{dec}$. Available from: Disponível em: $<\mathrm{http}: / / \mathrm{www} . \mathrm{sema}$. rs.gov.br/conteudo.asp?cod_menu=216\&cod_conteudo=7206>. Access in: 11 Fev. 2013.
RIZZO, L., 2011. Bioassays as a tool for evaluating advanced oxidation processes in water and wastewater treatment. Water Research, vol. 45, no. 15, p. 4311-4340. http://dx.doi.org/10.1016/j. watres.2011.05.035. PMid:21722938.

ROCHA, EMR., VILAR, VJP., FONSECA, A., SARAIVA, I. and BOAVENTURA, RAR., 2011. Landfill leachate treatment by solar-driven AOPs. Solar Energy, vol. 85, no. 1, p. 46-56. http://dx.doi.org/10.1016/j.solener.2010.11.001.

SCALON, MCS., RECHENMACHER, C., SIEBEL, AM., KAYSER, ML., RODRIGUES, MT., MALUF, SW., RODRIGUES, MAS. and SILVA, LB., 2010. Evaluation of Sinos River water genotoxicity using the comet assay in fish. Brazilian Journal of Biology $=$ Revista Brasileira de Biologia, vol. 70, no. 4, supplement, p. 1217-1222. http://dx.doi.org/10.1590/S151969842010000600011. PMid:21225163.

SCOTT, JP. and OLLIS, DF., 1995. Integration of chemical and biological oxidation processes for water treatment: review and recommendations. Environment and Progress, vol. 14, no. 2, p. 88-103. http://dx.doi.org/10.1002/ep.670140212.

TORRES, AC., NASCIMENTO, WM., PAIVA, SAV. and ARAGAO, FAS., 2003. Bioassay for detection of transgenic soybean seeds tolerant to glyphosate. Pesquisa Agropecuaria Brasileira, vol. 38, no. 9, p. 1053-1057. http://dx.doi.org/10.1590/ S0100-204X2003000900005.

TOUSSAINT, MW., SHEDD, T., VAN DER SCHALIE, WH. and LEATHER, GR., 1995. A comparison of standard acute toxicity tests with rapid-screening toxicity tests. Environmental Toxicology and Chemistry, vol. 14, no. 5, p. 907-915. http:// dx.doi.org/10.1002/etc.5620140524.

U.S. Environmental Protection Agency - USEPA, 1996. Proposed guidelines for ecological risk assessment. Washington: Risk Assessment Forum. (EPA 630-R95-002B).

VARNERO, MT., ROJAS, C. and ORELLANA, R., 2007. Índices de fitotoxicidad en residuos orgánicos durante el compostaje. Revista de la Ciencia del Suelo y Nutrición Vegetal, vol. 7, no. 1, p. 28-37

WANG, W., 1987. Root elongation method for toxicity testing of organic and inorganic pollutants. Environmental Toxicology and Chemistry, vol. 6, no. 5, p. 409-414. http://dx.doi.org/10.1002/ etc. 5620060509 .

WANG, X., SUN, C., GAO, S., WANG, L. and SHUOKUI, H., 2001. Validation of germination rate and root elongation as indicator to assess phytotoxicity with Cucumis sativus. Chemosphere, vol. 44, no. 8, p. 1711-1721. http://dx.doi.org/10.1016/S00456535(00)00520-8. PMid:11534903.

ŽALTAUSKAITĖ, J. and ČYPAITE், A., 2008. Assessment of landfill leachate toxicity using higher plants. Environmental Research. Engineering and Management, vol. 4, p. 42-47. 